\title{
Effective Supervision and Administration: A Panacea to Poor Quality Assurance in Vocational and Technical Education in Nigeria
}

\author{
Ogundola P. I. (Ph.D) \\ Department of Vocational and Technical Education \\ Faculty of Education, Ekiti State University, Ado Ekiti, Nigeria. \\ Fabamise D. B. \\ Department of Vocational and Technical Education \\ Faculty of Education, Ekiti State University, Ado Ekiti, Nigeria. \\ Fadipe O. O. \\ Department of Vocational and Technical Education \\ Faculty of Education, Ekiti State University, Ado Ekiti, Nigeria.
}

\begin{abstract}
Supervision, administration and quality assurance in vocational and technical education are three widely discussed concepts in any specialized skill-focused education. Ineffective or absence of supervision and administration has been discovered by policymakers as an inhibition to the realization of goals of vocational and technical education and its quality assurance. The purpose of this paper is to explore effective supervision and administration as a panacea to quality assurance in vocational and technical education in Nigeria; to examine the relevance of effective supervision and administration to vocational and technical education. The paper highlighted concepts and challenges of vocational and technical education, outcome of ineffective supervision and administration, quality assurance and its impact in vocational and technical education. This paper concluded that since the attainment of rapid technological and socioeconomic development of any developed economy is based primarily on Vocational and Technical Education, the supervision and administration of this type of education therefore, has to be effectively executed. Suggestions were made to this effect.

Keywords: Effective, Supervision, Administration, Panacea, Poor, Quality Assurance, Vocational and Technical Education, Nigeria.

DOI: $10.7176 / \mathrm{JEP} / 11-16-18$

Publication date:June 30th 2020

\section{Introduction}

The Federal Government of Nigeria is conscious of the importance of education for personal and national economic development that is in section 12: 107 (c) of the National Policy on Education (2004). This is set out as one of her objectives, to ensure quality control through regular and continuous supervision and administration of instructional and other educational services in Vocational and Technical Education. Effective supervision and administration are crucial issues in the delivery of Technical and Vocational Education as they are the main avenue through which technological and entrepreneurial exploits could be ensured for sustainable economic development. A critical issue that has frequently confronted Vocational and Technical Education in Nigeria is the challenge of effective administration and supervision.

The present situation of supervision in schools as reported by Ezekwensili, (2007), showed there has not been thorough supervision of schools in recent past decades. A system not supervised and evaluated is in dire need of collapse. National Policy on Education (2004), sees in many schools that there are lack of poor or ineffective supervision of personnel and instructional materials. It is the duty of the school administrators to supervise and monitor instruction regularly thereby enhancing quality assurance in Vocational Education programme and reducing inequalities within the horizontal and the vertical instructional delivery system of the programme. When supervision is absent, it leads to lack of communication, which leads to the indiscipline of students in the school. This lack of supervision and good administration in schools has been the bane of failure in Vocational and Technical Education in Nigeria Isa \& Jailani (2014). Its implication is poor quality assurance in the programme.
\end{abstract}




\section{Vocational and Technical Education in Nigeria}

Vocational and Technical Education according to Ojimba (2012) is a form of education whose primary aim is to prepare persons for employment in recognized occupation. This encompasses field of study (agricultural education, fine and applied arts education, business education and vocational trades in soap making, hairdressing, computer training among others). Vocational and Technical Education provides the recipients with the opportunities to develop their psychomotor, cognitive and affective skills, so that they can take their rightful places in the society and assume responsibility beyond their immediate environments. Subsequently, the National Policy on Education (2004) asserted that vocational education is a form of education that equips individuals with skills, abilities and competencies to equip themselves economically and contribute to the development of their society.

The National Policy on Education (2004) also expressed the vision of Vocational and Technical Education as follows

- $\quad$ To provide trained manpower in applied science, technology and commerce particularly at subprofessional grades.

- To provide the technical knowledge and vocational skills necessary for agricultural, industrial, commercial and economic development.

- $\quad$ To provide people who can apply scientific knowledge to solve environment problem for the use and convenience of man.

- To give an introduction to professional studies in engineering and other technologies.

- To give training and impart the necessary skills leading to the production of craftsmen, technicians and other skilled personnel who will be enterprising and self-reliant.

- To enable our young men and women to have an intelligent understanding of the increasing complexity of technology.

In Nigeria, Vocational and Technical Education has long been perceived as critical to national development. Unfortunately, it has not been accorded the seriousness it deserves. The cumulative result is that today, Vocational and Technical Education in Nigeria is in a terrible shape, crippled by a general, persistent and chronic crisis in terms of funding, staffing, curricula, infrastructure and facilities as submitted by Okolocha \& Baba (2016). Successive Nigerian governments have for long pursed poorly planned and disjointed educational policies with profound and devastating consequences on the development of the country. For example, our educational system has witnessed series of transformation without achieving the desired goal.

Similarly, international agency such as Amoor (2009) has a misconception that Vocational and Technical Education is an education that is meant for the dropouts, unintelligent and non-achievers. This misconception has in no small measure frustrated the enrolment of candidate into the vocational and technical education programme in tertiary institutions. It has also affected youth's enrolment into artisan jobs. Everybody wants to play politics that is now more lucrative than anything else. This poses a great challenge in Vocational and Technical Education in Nigeria.

\section{Challenges Facing Vocational and Technical Education in Nigeria.}

There are numerous challenges facing Vocational and Technical Education in Nigeria which have affected negatively the nations' development. Among these challenges are:

\section{Public Perception and Apathy to Vocational Education.}

Vocational and Technical education in Nigeria has a very low image and there is a need for a turn around on its perception for public acceptance. Observations have shown that many parents especially the elites, the rich and the political class do not encourage their wards to make Vocational and Technical Education a career and those people who opt probably for Vocational and Technical Education programme either by accident or chance are not motivated or encouraged because the society does not place any significant value or dignity on the programme. (Kennedy, Udoetuk \& Ufot 2017)

In Nigeria today, how many ministers, governors, local government chairmen, professors and even teachers of Vocational and Technical Education do encourage their siblings to enlist for Vocational and Technical Education certificates? Rather, they prefer them to study courses like pharmacy, medicine, law, 
accounting among others. Kennedy et.al. (2017) opined that, boosting the image of Vocational and Technical Education should be a serious concern to Vocational and Technical Education practitioners, institutions and other stakeholders. For the purpose of this paper, ineffective supervision and administration in Vocational and Technical Education will constitute the major challenges that will be discussed in this paper.

\section{Supervision and Administration in Vocational and Technical Education.}

The concept, supervision is often referred to as instructional supervision in order to reflect the content in which the supervision is undertaken. Very often too, supervision is used interchangeably with inspection or school inspection. Yet some literature makes certain distinctions between Inspection and Supervision. Inspection belongs to the British tradition while supervision originated from the American tradition. Supervision seems to mean different things to different people. Supervision means overseeing the performance of a person or a group. It means to check the performance of workers and to guide them accordingly. According to Nwagwu (2004), supervision is an important requirement in educational management that concerns itself with the tactics of efficient and effective management of human and material resources. And also Aguokagbuo (2002), defined supervision as a way to advice, guide, refresh, encourage, stimulate, improve and oversee teachers in the hope of seeking their co-operation in order that they may be successful in the task of teaching and classroom management.

Similarly, Figueroa (2004), defines supervision as a process of guiding, directing and stimulating growth with the overall view of improving teaching and learning process better for the leaner. It directs the activities, controlled and monitors the functions of the different units of the system. Unfortunately, the total commitment required in the administration and supervision of most technical colleges in the country is below expectation. The inadequacies and laxities in and amongst the staff of most vocational and technical schools in the country further underscore the need for effective supervision in those schools today. It has been observed that, the major problem confronting Vocational and Technical Education is the use of non-professional in handling VTE matters. Ibeneme (2007) noted that many administrators of Vocational and Technical Education programme at policy making level are not vocationally trained persons and thus do not seem to understand the needs of the programme regarding fund distribution.

As a result, the administrators and teacher do things as they like. An effective administrative and supervisory role can only be achieved with leadership role which must be carried out with the aim of achieving the overall goals of the policy. The Social Care Institute for Excellence (SCIE, 2001) emphasizes how effective supervision and administration are key components in staff leadership and management which can lead to the following improvements:

* Greater individual motivation

* The ability to plan workload

* More effective coordination of work

* Learning on the job

* An understanding of how work links into overall objectives

If education would be one of the tools to realize the objectives of transformation agenda of the present government in Nigeria, there is a need to improve upon the quality of learning in Vocational and Technical Education through effective supervision of instruction Ekundayo, Oyerinde \& Kolawole (2013). Less supervision causes gross negligence and often causes low morale and low productivity amongst students. It has been observed that, there seems to be some precursors to poor supervision and administration in Vocational and Technical Education in Nigeria. These include:

\section{Inadequate funding of Vocational and Technical Education Programme at all levels.}

The realization of the objectives of technical education is made possible with adequate finance with which essential facilities are procured and human capacity is built. A sustain and adequate financial support to education is panacea to the present groaning of Vocational and Technical Education Programme in Nigeria as opined by Isa \& Jailani (2014). This is a reality considering the fact that changes in the educational system requires not only policy making, but implementation through adequate financial support.

\section{Poor capacity building among major stakeholders}

In order to ensure adequate and effective supervision of instruction in Vocational and Technical Education Programme in Nigeria, government need to embark on capacity building of supervisors, administrators as well as teachers to enable them perform their duties effectively. This can be done through regular training, induction programmes, seminars and workshops to equip them with necessary skills and keep them abreast of the current trends in the school system. They can equally be given opportunities to participate in 
international conferences in other to acquit themselves with what operates in the school system outside the shores of Nigeria (Asogwu, Ugo \& Isiwu 2016).

\section{Shortage of Qualified and Experience Teachers}

The dearth of qualified and experience teachers in most of the technical colleges in Nigeria is one of the major challenges of Vocational and Technical Education development. Ayonmike, Okwelle \& Okeke (2015) found that some of the challenges facing Vocational and Technical Education in Nigeria are poor teaching methods employed by teachers, teachers' lack of interest to teach, poor research attitude of teachers, poor preparation of lesson by teachers and so on This has affected the production of qualified Vocational and Technical Education teachers. The result of this is shortage of qualified teachers to handle these subjects/trades in tertiary institutions thereby producing half-baked graduates. The school management in order to fill the gap makes use of unqualified teachers. Its consequences is the graduation of untrained and unqualified graduates of Vocational and Technical Education programme who are jobseekers instead of self-employed and job creators..

\section{Employment of supervisors with lower educational qualifications}

Supervisors with higher qualifications are more likely to perform better in the field than those with lower qualification as education personnel with higher qualifications display more confidence in their workplace as submitted by Boaduo in Isa \& Jailani (2014). In addition, they are more accessible to quality information, and adapt to changing occupational conditions than their counterparts with lower qualification, who are usually more indisposed and ill-equipped in adapting to modern changes. All these account for ineffectiveness in supervision in Vocational and Technical Education programme VTE and affect its quality assurance. Events have shown that countries and individuals are not able to harness human and non-human resources efficiently towards the realization of specific socio-economic and technological goals which brings us to the fact that there is need for ensuring quality assurance in Vocational and Technical Education programme.

\section{Quality Assurance in Vocational and Technical Education}

Quality can be described as standard of something as compared to other things, that is, the degree of excellence (Idialu, 2013). High quality teaching/instruction can be regarded as the effectiveness in teaching/instruction which can result in student learning and satisfaction. Quality teaching and learning in Vocational and Technical Education therefore ensures that students acquire the knowledge, skills and competences that are appropriate for their area of responsibility. There is the need to have teaching standards and develop challenging examinations to document and recognize accomplished teaching. Quality assurance is an essential tool required to ensure efficient Vocational and Technical Educational programmes in our schools for the achievement of manpower development and skill acquisition in our societies.

Quality assurance as described by Idialu (2013), are ways of managing the educational sector, the service provided to ensure that they are kept at high standard that will positively affect its products. It involves injecting quality into the process of training from the very beginning to ensure that the products meet a specified standard. For Vocational and Technical Education to attain quality, it requires working with already established procedures and standards as established by regulatory agencies in the different countries. For example, in Nigeria we have the National Universities Commission (NUC), National Board for Technical education (NBTE), National Commission for Colleges of Education (NCCE) and so many others. These are agents of ensuring quality in Vocational and Technical Education (Onyesom and Ashibogwu, 2013).

The duty of ensuring quality actually rests on the teachers/lecturers who are directly in charge of implementing the educational programmes. Quality assurance in vocational education must be viewed holistically from requirements of entry into the programme, duration, quality and number of teacher/lecturers, facilities, instructional materials available, school environment/accommodation, examinations, results, certificate, grading system, exam question items, supervision, moderation among others. These are not farfetched from what to be supervised in Vocational and Technical Education, as submitted by Agih (2015). These include; the school programme and resources, assessment of Principals (other head teachers), the teachers, the non-academic staff, the students/ Pupils, the school plants (facilities and equipment), the school account, the school project and school record among others..

It has to be a total package to ensure a meaningful product (Idialu, 2013). The concept of quality assurance hinges on education supervision. Which is a complete concept aimed at systematically linking planning, analysis and control. Quality assurance must, therefore, involve internal and external influence to ensure efficiency and benefit desired. 


\section{Impact of Quality Assurance in Vocational and Technical Education}

Vocational and Technical Education cannot function properly unless there is high quality in the standard of teaching, materials available, teaching methods and proper evaluation of students in the programme. The assessment of quality teaching is an on-going, multi-dimensional process which should be based on process and product. The following are some of the benefits accrued from quality assurance in Vocational and Technical Education.

\section{Improvement of Classroom Instruction}

The improvement of classroom instruction is a fundamental function of administration-supervision of vocational and technical education. This improvement means much more than merely the improving of teaching methods. It involves the provision of the right content, to the right group, at the right time, in the right place, and using the right methods. Improvement of classroom instruction does not just happen. There are few established guideposts available to follow in providing for the improvement of vocational instruction. The impetus needed for change must come from somewhere (administration and supervision of Vocational and Technical Education is the logical source. (Williams in Agih 2015). Instructional effectiveness is one aspect of teaching success. Effective classroom instruction is evidenced by the teacher, whose students show the largest gain over their pre instructional status, by the teacher whose students learn the most from classroom instruction.

\section{The Improvement of Classroom}

Instruction by a particular vocational teacher is directly related to the achievement of professional growth. If the Vocational and Technical Education department is to be alive and dynamic, it is essential that the administrator - supervisor stimulate and develop a departmental attitude that is conducive to academic stimulation in which the result will be a professional growth and the improvement of classroom instruction (Agih 2015).Procedures for improving classroom instruction may vary from school to school. They are dependent upon the size of buildings, student enrollment, available space for the Vocational and Technical Education programme, technical equipment and materials, and the attitude of each vocational teacher. The interest, aptitude, and abilities of vocational students and the philosophy, background, and experiences of the administrator- supervisor of Vocational and Technical Education are all factors in a programme of professional growth and the improvement of classroom instruction. The problem is to maintain a proper balance of each factor that is involved. Furthermore, Maclean (2011) asserts that Vocational and Technical Education if well positioned with effective quality assurance, could play multidimensional roles of stimulating economic growth, social development, improving conventional education, empowerment, wealth creation, poverty reduction and skills enhancement.

\section{Conclusion}

Vocational and Technical Education has an illustrious part, which is the training and the development of individuals to be successful in any career of their choice. As a result of this, it should be accorded its rightful place in national development. It is high time that government and the Nigerian society are enlightened on the benefits of Vocational and Technical Education which will actualize the goals of vision 20:2020 of the present government. These benefits may not be achievable if Vocational and Technical Education is piloted by poor and ineffective supervision and administration. Effective supervision and administration in Vocational and Technical Education must be accorded priority attention so as to enhance quality assurance in Vocational and technical Education. When this is achieved, a more responsive Vocational and Technical Education would be established as to meet the ever evolving demands of Nigerians towards our technological development since the attainment of rapid technological and socioeconomic development of any developed economy is based primarily on Vocational and Technical Education,

\section{Recommendations}

Based on the content of this paper the following were recommended:

1. Adequate budgetary allocation should be made for Vocational and Technical Education due to the capital intensive nature of the programme.

2. Vocational and Technical educators should be actively involved in policy formulation, implementation, administration and supervision of Vocational and Technical issues in Nigeria. 
3. The Federal Government of Nigeria should begin now to take very seriously investment in Vocational and Technical Education and become not only the most populous country in Africa, but also the most competitive country in international labour market.

4. Effective supervision and administration of all the Vocational and Technical Education programmes in Nigerian schools should be of great priority to ensure quality assurance and avoid wrong application of methodology to teach the students.

5. Better conditions of service should be put in place for Vocational and Technical educators. This will serve as incentives for effective supervision and administration.

6. The Federal Government of Nigeria should give more attention to Vocational and Technical Education and come up with strategic plans, policies and practices for vocational and technical development of people.

\section{References}

Agih, A. A. (2015). Effective School Management and Supervision: Imperative for Quality Education Service Delivery. An International Multidisciplinary Journal, Ethiopia 9(3), 62-74.

Aguokagbuo, C.N. (2002). Micro-teaching theory and practice Nsukka: Mike Social press. Isa, Y. K. \& Jailani, B. M. (2014). The Processes of Supervisions in Secondary Schools Educational System in Nigeria. Congress on Technical and Vocational Education and Training (WoCTVET), Malaysia.

Amoor, S.S. (2009). The challenges of vocational and technical education programme in Nigerian Universities. Retrieved from from: www.abu.edu.ng/publications.

Asogwa, V.C., Ugo P. \& Isiwu, E. C. (2016). Capacity Building Approaches for Enhancing Quality Assurance of Teachers of TVET Programmes for Job Creation and National Development. Conference Paper. Association of Vocational and Technical Educators of Nigeria. (JAVTEN), at Taraba State, volume 21.

Ayonmike, C. S., Okwelle, P. C. \& Okeke, B. C. (2015) Towards Quality Technical Vocational Education and Training (TVET) Programmes in Nigeria: Challenges and Improvement Strategies. Journal of Education and Learning. 4(1),25-34.

Boaduo, N.A.P. (1998). An investigative study of innovation and reform in the education system of the Kingdom of Lesotho. Summary of Ph.D. dissertation. African Journal: An Online Journal of African Educational Research Network. March-May, 2005. 5(1), 4-19.

Ekundayo, H.T.,Oyerinde ,D. O., Kolawole, A. O. (2013).Effective Supervision of Instruction in Nigerian Secondary Schools: Issues, Challenges and the Way Forward. Journal of Education and Practice 4(8), 185-190

Ezekwensili, O. (2007). Reinventing Education. Vanguard Newspaper, Daily Jan 4, Pg 47

Figueroa, R.A.N. (2004). Actual and destined teacher attitudes toward supervision of instructional strategies in pedagogical and curriculum areas in high and low performance in secondary schools.

Ibeneme, O.T. (2007). Vocational and technical education: Nigeria's imperative for achieving the first millennium development Goal Initiative. Journal of Research and Development.2(1).

Idialu, E. E. (2013). Ensuring Quality Assurance In Vocational Education. Contemporary Issues in Education Research (CIER), 6(4), 431-438. https://doi.org/10.19030/cier.v6i4.8112

Kennedy, G. W., Udoetuk, U. S. \& Ufot, S. I. (2017). Challenges of Technical Vocational Teacher Education and Teaching in Nigeria: The Need for Intervention. International Journal of Education and Evaluation. 3 (7).

71-82. www.iiardpub.org

Maclean, R. (2011). Key Issues and Research Challenges for TVET: Bridging the gap between TVET research and the needs of policy makerse, in NORRAG NEWS, Towards a New Global World of Skills Development? TVET's turn to Make its Mark, 46, 125-127 
Nwagwu, C.C. (2004). Organization and Administration of Education: Perspective and Practices Benin City: Festa Publishing Press.

Ojimba, P.D. (2012). Vocational and technical educational in Nigeria: issues problems and prospects. Dimension (IPP) Journal of Education and Social Research, Rome, Italy, 2(9), 23-30.www.mcser.org.

Okolocha, C.C. \& Baba, E. I. (2016). The Role of Vocational and Technical Education (VTE) in Nigeria Democratic Dispensation. International Journal of Capacity Building in Education and Management (IJCBEM) 2(4): 12-24 Website: http://www.rcmss.com.

Onyesom, M. \& Ashibogwu N.K. (2013). Towards Quality Assurance in Business Education in Nigeria: Constraints and Control. Asian Journal of Business \& Management. 3: 306 - 312

The Social Care Institute for Excellence (2001). Supervision: Leadership Learning Pathways for Scotland's Social Services http://www.scie.org.uk/publications/guides/guide01/index.asp. Scotish Social Services Council.

Williams, E. (1968). The Administration and Supervision of Business Education Conceptually Defined. $A$ Dissertation submitted to the University of Oklahoma, Ed.D., Education Administration University Microfilms, Inc., Ann Arbor, Michigan. 